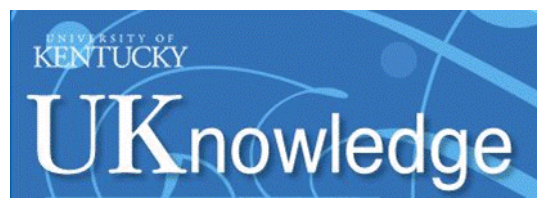

University of Kentucky

UKnowledge

Fall 2018

\title{
Blurring Institutional Boundaries: Judges' Perceptions of Threats to Judicial Independence
}

\author{
Alyx Mark \\ North Central College \\ Michael A. Zilis \\ University of Kentucky, michael.zilis@uky.edu
}

Follow this and additional works at: https://uknowledge.uky.edu/polsci_facpub

Part of the Judges Commons, Legislation Commons, and the Political Science Commons

Right click to open a feedback form in a new tab to let us know how this document benefits you.

\section{Repository Citation}

Mark, Alyx and Zilis, Michael A., "Blurring Institutional Boundaries: Judges' Perceptions of Threats to Judicial Independence" (2018). Political Science Faculty Publications. 3.

https://uknowledge.uky.edu/polsci_facpub/3

This Article is brought to you for free and open access by the Political Science at UKnowledge. It has been accepted for inclusion in Political Science Faculty Publications by an authorized administrator of UKnowledge. For more information, please contact UKnowledge@lsv.uky.edu. 


\title{
Blurring Institutional Boundaries: Judges' Perceptions of Threats to Judicial Independence
}

\author{
Digital Object Identifier (DOI) \\ https://doi.org/10.1086/695743 \\ Notes/Citation Information \\ Published in Journal of Law and Courts, v. 6, no. 2, p. 333-353. \\ (C) 2018 by the Law and Courts Organized Section of the American Political Science Association. All rights \\ reserved.
}

The copyright holder has granted the permission for posting the article here.

This article is available at UKnowledge: https://uknowledge.uky.edu/polsci_facpub/3 


\title{
Blurring Institutional Boundaries
}

\author{
JUDGES' PERCEPTIONS OF THREATS TO JUDICIAL \\ INDEPENDENCE
}

A L YX MARK, North Central College

M I C H A E L A. Z I L I S, University of Kentucky

\begin{abstract}
The legislature wields multiple tools to limit judicial power, but scholars have little information about how judges interpret variant threats and which they find most concerning. To provide insight, we conduct original interviews regarding legislative threats to courts with over two dozen sitting federal judges, representing all tiers of the federal judiciary. We find that judges have a nuanced understanding of threats and tend to identify components of legislative proposals that threaten formal institutional powers as more concerning than those challenging policy set by judges. This distinction has broad implications for our understanding of judicial behavior at the federal level.
\end{abstract}

Numerous studies investigate the perennial struggle for authority between Congress and the federal judiciary, and we know a great deal about specific types of legislative threats toward the judiciary and reactions at the court level. Yet, we know far less about how judges perceive and interpret interinstitutional conflict at the individual level. How do judges process the full complement of threats from Congress, and what are the consequences for the study of the separation of powers? Since judges may face crosscutting pressures at any given time (Epstein and Knight 2013), it is important to understand how judges process and react to these variant balances of threats. Studying voting behavior is one approach to do so. Here, we adopt another tactic and conduct interviews with sitting federal judges about their perceptions of threats to judicial independence. This approach enables us to trace some of the underlying perceptions and motives that influence judicial behavior in light of congressional threats. In other words, we allow judges to elucidate the particular

We are grateful to the anonymous reviewers and editor of the Journal of Law and Courts for their thoughtful comments and helpful criticism. We would also like to thank Laura Moyer, Ryan Owens, Justin Wedeking, and our panel at the 2016 meeting of the Midwest Political Science Association for their comments on an earlier draft of this article. Contact the corresponding author, Alyx Mark, at alyxmark (a)gmail.com.

Journal of Law and Courts (Fall 2018) ( 2018 by the Law and Courts Organized Section of the American Political Science Association. All rights reserved. 2164-6570/2018/0602-0005\$10.00. Electronically published May 25, 2018. 
aspects of legislative attacks that are most concerning to them, which is an important innovation, as Congress forwards many at a given time (Toma 1991; Clark and McGuire 1996; Ross 2002; Clark 2011).

We propose a novel way to conceptualize legislative threats to the courts and examine this framework using an original set of data based on our interviews with 27 sitting federal judges, representing all levels of the judicial hierarchy. ${ }^{1}$ We aim to provide a portrait of how federal judges distinguish and evaluate the relative importance of threats given their policy-based and institution-focused content, which may in turn have implications for their behavior. We find that judges discern the seriousness of a threat by weighing the effects of specific legislative provisions on the judiciary's ability to secure a variety of goals it cares about, including independence, discretion, and long-term policy gains. That is, while judges are concerned both about threats to their institutional power and about those to their current policy preferences, they make a distinction between a legislative provision they view as a symmetrical response to an unfavorable decision (i.e., a policy-based response) versus an asymmetric threat, like a provision that attacks the institution itself. In other words, while judges are aware of the range of constitutional powers Congress possesses that may be used to correct the courts, they view institutional restrictions as a form of intimidation warranting particular concern. In contrast, federal judges tend to perceive shifts in policy as proportionate responses to disfavored legal change within a separationof-powers system.

Our judge respondents show strong support for a more nuanced view of the threats the judiciary faces. We learn that an overwhelming majority of judges (85\%) believe that proposals that contain provisions to threaten the integrity and independence of the judiciary are most concerning. Of these, nearly half of judges (43\%) are most concerned about congressional efforts to slash budgets and salaries within the court system, while others described concerns about judicial-retention reforms and congressional oversight. Only a small number of federal judges we interviewed (7\%) cite provisions to alter judgemade policies as most concerning. Moreover, many of the judges we talked with mentioned that the mechanism underlying their concerns is the view that institutional threats like court curbing are asymmetric responses to judicial action; in other words, they are disproportionate in nature.

Adding nuance to the dualistic view of congressional threat behavior will help to refine scholars' understanding of interbranch dynamics. Rather than focus on legislative actions that aim entirely at policy that judges set or the judiciary as an institution, we con-

1. Although we interview a substantial subset of sitting federal judges, most of whom readily acknowledge threats faced by the court system, we (of course) do not believe this tells the complete story of interinstitutional conflict. But we recognize that the existing literature, in overwhelmingly focusing on voting outcomes, is also only able to tell a portion of the story. We hope to spur dialogue about other forms of evidence that could be used to shed light on the complexities of judicial behavior when interinstitutional conflict is involved. 
sider how proposals may contain multiple threatening elements. Because our interviewees are able to identify the components of congressional threats they find to be most worrisome, this suggests that federal judges tend to feel more targeted by a legislative proposal with an institutional restriction embedded than by one that does not include such a constraint. Additionally, even though Congress rarely passes institutional threats into law, judges identify multiple ways they feel compelled to adjust their behavior in order to preempt these threats, a fact which has implications that should enrich future research on judicial responsiveness. As such, we contribute to the separation-of-powers literature one of the first examinations of the extent to which judges pay attention to, demonstrate concern over, and consider responses to legislative proposals that threaten their authority. This insight suggests to us that more attention should be paid to asymmetric, or institutional, threats in future work on interinstitutional conflict.

\section{EXTANT SCHOLARSHIP ON JUDICIAL RESPONSES TO CONGRESSIONAL THREATS}

Existing research points to two routes through which Congress may threaten the independence of judges: policy-based and institution-focused proposals. Although some proposals may be squarely categorized as policy based or institutional, some may also have elements of both, raising questions as to the types of provisions about which judges are most concerned, particularly in a complicated threat environment. Resolving these questions is important to understanding the precise conditions under which judges may adjust their behavior so as to shield themselves from the crosshairs of lawmakers.

First, legislation may contain provisions that offer a policy-based response to judicial decisions. This represents a threat to the extent that a judge is concerned that a lawmaking authority like Congress will overrule her decision. In other words, a policy-based provision is one in which a legislature seeks to articulate a new policy or set of policies, through the passage of legislation, in an area in which courts have themselves set policy. This view puts policy-based threats squarely within a long theoretical tradition that considers judges as policy-motivated actors who nonetheless must behave strategically to forestall legislative reversals (e.g., Ferejohn and Weingast 1992; Sala and Spriggs 2004; Harvey and Friedman 2006). ${ }^{2}$

Quite distinctly, legislation may also include institutional threats, or attacks by legislators that seek to limit the formal or institutional authority of the courts, which represent a more direct challenge to the judiciary (Toma 1991; Clark 2011). In other words, institutional threats are often characterized by the legislative attempt to limit the general independence or future discretion afforded to the judiciary, either broadly or in a more specific

2. Of course, the rich literature on the potential for policy reversals has yielded contradictory findings as well. Some doubt whether the policy-based threat has any teeth, finding evidence that sincere behavior is much more prevalent than sophisticated decision making, at least at the Supreme Court (Segal 1997). 
area of the law. Toma (1991) and Rosenberg (1992) helpfully catalog a variety of tools that Congress has at its disposal to sanction the judiciary, which include tactics like jurisdiction stripping (a common tool), budget slashing, the imposition of term limits, and alterations in the size of the bench. Additionally, Congress often issues vague "warnings" to the judiciary about its behavior in pending cases. Some work suggests that reliance on these tools is cyclical, with Congresses varying in their willingness to engage in court-curbing behavior (Nagel 1964). ${ }^{3}$ There is also some evidence to suggest that judicial behavior is indeed influenced by these attacks (Clark 2009; Segal, Westerland, and Lindquist 2011).

Although the work of Clark $(2009,2011)$ has recently reoriented this literature by drawing renewed attention to court-curbing proposals forwarded by Congress, only a limited number of studies, often descriptive in nature, consider the systematic effects these threats may have on judicial behavior (see Toma 1991; Rosenberg 1992). One reason for the limited attention paid to institutional threats may be the fact that they are generally perceived as unlikely to be realized. Congress's track record in passing court-curbing legislation is limited (Ross 2002; Farganis 2009) — which is not, however, to say that the threat is nonexistent. ${ }^{4}$ Even work that does consider the institutional threat more systematically often suggests that policy concerns are central to the inquiry. For instance, the examinations of judicial review by Whittington $(2003,2005)$ show that courts enjoy this authority but only to the extent that the balance of their policy making is desired by the legislature on the whole. And further, we note that there is little empirical evidence or theoretical extension of either of these perspectives to the lower federal courts, despite work suggesting that these courts, particularly at the circuit level, also play a significant role in policy making (but see Moyer and Key 2016; see also Songer, Sheehan, and Haire 2000; Bowie, Songer, and Szmer 2014). ${ }^{5}$ Thus, the literature leaves unanswered questions about how judges, at all levels of the hierarchy, interpret and perceive the mix of threats that they may face. Policy-based and institution-focused threats are both present in a complex, interinstitutional environment, yet the literature tends to study them in isolation and emphasize the former. Without understanding the entire spectrum of threats judges encounter, it may be difficult to determine how they use this information to inform their behavior.

3. Historically, even if court-curbing bills were not passed by Congress, there is evidence that the political pressure placed on the judiciary through repeated attacks may have been enough to move judicial behavior without formalized action (see generally Ross 1994). One mechanism is that the proposal of legislation signals to the judiciary its declining popular support, causing judges to adjust their behavior to stave off a further loss of public confidence (Clark 2009, 2011).

4. We suggest that, even during periods in which few institutional threats are advanced, the judiciary may possess a degree of institutional memory about previous struggles for authority. This should lead judges to be apprehensive about even subtle signals that take the form of institutional threat.

5. We distinguish our work from others that consider the nature of strategic anticipation from within the branch, such as circuit judges' (lack of) behavior modification in light of potential Supreme Court reversal (Bowie and Songer 2009), and instead focus on a model informed by threats from outside of the branch itself. 
To more fully illustrate the mix of threats judges face, we consider two examples: Congress's response to Texas v. Johnson (491 U.S. 397 [1989]) and the development of the Federal Sentencing Guidelines in 1984. Following controversial rulings in the state of Texas and at the Supreme Court in Texas, Congress put forward a series of bills on flag burning. These were aimed at overturning the broad First Amendment protections put in place by the courts. ${ }^{6}$ This legislation represented a clear threat to judge-made policy. Also during this time, the judiciary was the focus of House Joint Resolution 15, which aimed to limit the length of time that judges could serve on the bench. This more general proposal was targeted at the institution itself, which exemplified a more direct risk to judicial independence and the integrity of the courts. ${ }^{7}$ The separation-of-powers literature would suggest that judges had reason to be concerned about both types of proposals, yet it gives little guidance on how they would weigh the relative importance of these threats. This has implications for the eventual actions that these judges may take, since it is reasonable to expect that strategic actors are more likely to respond to the threats they find most troublesome.

As our second example of threat complexity shows, even a single piece of legislation may include policy-based and institutional components, thereby making it difficult to classify it as wholly one type of threat or the other. The Federal Sentencing Guidelines, as proposed by the Sentencing Reform Act of $1984,{ }^{8}$ set broad policy parameters regarding the nature of criminal justice in the United States while, at the same time, limiting the discretionary authority and eroding the institutional independence of judges. The imposition of the Sentencing Guidelines via the act signaled a shift in the institutional power in criminal law and sentencing policy from the judiciary to Congress, which significantly reduced the discretion of judges in all future cases that fell within the boundaries of the sentencing chart (Nagel and Swenson 1993). This shift represented a dramatic change in the institutional purview of the judiciary, as well as severely limited its power in the realm of criminal justice policy. ${ }^{9}$

We contend that compartmentalizing the study of congressional threats limits our ability to answer key questions that are relevant to the relationship between Congress

6. For instance, the Flag Protection Act aimed to criminalize flag burning (this law was ultimately struck down).

7. We also note that House Joint Resolution 15 broadly targeted all federal judges, which we believe may have consequences for their behavior. District court judges, e.g., might feel even more vulnerable to such a proposal than their colleagues that serve on courts of higher visibility—although the literature has paid little attention to the reactions of lower courts to these types of institutional threats.

8. The Sentencing Reform Act was one component of the omnibus Comprehensive Crime Control Act of 1984 .

9. To further entangle the policy-based and institutional consequences of the Sentencing Reform Act for the judiciary, see Justice Scalia's dissent in Mistretta v. United States (488 U.S. 413 [1989]), in which he argues that the act, by moving a policy-setting authority to the independent United States Sentencing Commission, effectively removed that authority from both the judiciary and Congress, while also limiting the judiciary's decisional independence (488). 
and the courts. As a result, we know little about how the judiciary perceives the matrix of threats forwarded by Congress, sometimes within the space of a single bill. ${ }^{10}$ Moreover, there have been few attempts (but see Segal et al. 2011) to explore the relative weight that strategic judges assign to these variant threats, and even then questions remain as to how individual judges interpret the threats, since case outcomes are often the focus. It may further be the case that judges not only adjust their voting behavior but also make a wide variety of adjustments with interinstitutional threats in mind. By focusing on descriptive evaluations made by judges themselves, we are better equipped to understand the variety of adjustments they make in light of congressional threats.

\section{REASSESSING WHICH THREATS MATTER TO JUDGES}

In order to evaluate the relationship between congressional threats and the judiciary as perceived by some of those most keenly aware of this interplay, we sampled from a population of currently sitting federal judges and utilized an open-ended interview design. The open-ended interview method employed here uses a standardized set of interview questions, which allows for the ease of data analysis (Patton 1990). Further, the open-ended interview method allows for a high level of participant engagement in the research process, allowing the participant to use her own words in describing her reactions to a question. Open-ended interviewing also provides the researcher opportunities to clarify and extract additional themes in each interview, depending on the responses of the participant (see generally Kvale and Brinkmann 2009). Elite interviewing methods also offer comparative value in their ability to trace the relationships about which researchers care (Tansey 2007), such as the one here between legislative threats and judicial perceptions. ${ }^{11}$ For the purposes of this study, we consulted with academics in this field regarding the most appropriate bat-

10. We know considerably more about the factors that govern the calculations of Congress when it comes to sanctioning the courts. One line of literature emphasizes the value of judicial independence to lawmakers in general (Landes and Posner 1975; Graber 1993; Rogers 2001) or, more recently, members of the governing majority (Whittington 2005). Others see legislative action against the courts as a position-taking endeavor, which, as such, may lose value when the judiciary enjoys public support (Vanberg 2001; Clark 2009; Ura and Wohlfarth 2010). Nonetheless, a full accounting for the strategic calculations made by Congress when it chooses to threaten the judiciary is beyond the scope of this inquiry.

11. This method also has its shortcomings. Tansey (2007) notes four particular threats to making reliable inferences from elite interview data: the propensity of subjects to misrepresent their positions, to inflate or minimize their roles in policy making, to overemphasize their carefulness in the immediate aftermath of an event, and to be plagued by an inability to remember. Of these, misrepresentation is the most significant concern. However, we anticipate that the most likely misrepresentation should bias against identifying institutional threats as serious, since judges may not want to be viewed as involving themselves in political affairs or criticizing a legislature that they fear may sanction the judiciary. This squares with Posner's (2010, 2-3) observation that “most judges are cagey, even coy, in discussing what they do. They tend to parrot an official line about the judicial process ... of doctrines unmarred by willfulness, politics, or ignorance." In other words, we believe that the judges we interviewed were more likely to conceal by denying that political threats exist than vice versa. 
tery of questions for the sample. The resulting set of open-ended questions was the most appropriate data-collection strategy for the exploratory nature of this inquiry.

Over the course of 2 months, we interviewed 27 sitting federal judges via telephone. ${ }^{12}$ Judges were asked questions about their perceptions of threats to the judiciary and judicial independence. More specifically, they were asked whether they viewed judicial independence as something currently under threat, and if so, whether they could provide an example or additional detail about the nature of the threat. ${ }^{13}$ This open-ended question allowed judges to articulate specific provisions or elements about which they were most concerned in the threat environment. Interview participants came from a wide variety of previous career experiences and educational backgrounds. ${ }^{14}$ As detailed in table 1, of the 27 judges interviewed, Republican presidents nominated 13 and Democratic presidents nominated 14 , which is roughly representative of the current population of federal judges. ${ }^{15}$ The interview participants represented all levels of the federal judiciary, with a majority of the participants serving as district court judges. The sample of interviewees included 17 district court judges, 5 circuit court judges, 1 Supreme Court justice, and 4 Court of International Trade judges. Judges interviewed were also broadly representative of each available decade of commission within the population of currently serving judges. ${ }^{16}$ The judges represented almost every US circuit, including the federal and DC circuits, with only the Third Circuit not included in the sample. Judges interviewed were slightly less likely to be female than those in the federal court system as a whole; approximately $15 \%$ of the interviewees were female as compared to about $26 \%$ of the federal judiciary.

\section{RESULTS}

The balance between the judiciary and Congress has changed. ... There are constantly attempts to erode the jurisdiction of the federal courts. Congress has real power, and can limit our jurisdiction. We are dealing with that all the time. ... I worry about those efforts. They are certainly ongoing.

—Comment from a sitting federal appellate judge

12. The pool of potential interview candidates resulted from the authors' access to judges affiliated with a particular committee of the judicial branch. As a result of this connection, the authors were permitted to contact 61 federal judges and received a response rate of approximately 44\%. To note, the judges contacted were not all members of this particular committee but were merely those whom the authors were allowed to contact as a result of their relationship with the committee.

13. Further, judges were not informed in advance about the subject matter of the interview; they were told merely that they were going to be asked "questions about their experiences working as judges." As such, we do not expect that the judges agreeing to participate in the interview were more or less likely to have strong feelings about the interbranch dynamics at issue in this article.

14. Identifying information about the specific judges interviewed is omitted from this article as required by the approved Institutional Review Board protocol pertaining to this project's implementation.

15. All demographic information regarding the current makeup of the federal judiciary is derived from McMillion (2014).

16. One commissioned in the 1970 s, 5 in the 1980s, 8 in the 1990 s, 7 in the 2000s, and 6 in the 2010s. 
Table 1. Comparison of Judges Interviewed and Federal Judge Population (\%)

\begin{tabular}{lcc}
\hline & $\begin{array}{c}\text { Among Judges } \\
\text { Interviewed }\end{array}$ & $\begin{array}{c}\text { Among } \\
\text { All Judges }\end{array}$ \\
\hline Position within the federal judiciary: & & \\
$\quad$ District court & 63 & 78 \\
Appellate court (including USSC) & 22 & 21 \\
Court of International Trade & 15 & 1 \\
Background characteristics: & & \\
Female & 15 & 26 \\
Democratic appointee & 52 & 52 \\
Appointing president: & 4 & 2 \\
Nixon & 15 & 14 \\
Reagan & 4 & 9 \\
G. H. W. Bush & 30 & 21 \\
Clinton & 26 & 22 \\
G. W. Bush & 22 & 24 \\
Obama & & \\
\hline
\end{tabular}

Source.-Data on federal judges from the Federal Judicial Center.

Note.-Percentages rounded; may not sum to $100 \%$. USSC = US Supreme Court.

Participant judges were asked whether they perceived a threat to judicial independence and, based on their response, to elaborate on the presence or absence of this threat. This broad question was chosen so that judges were able to articulate any type of threats they sensed, including concerns about various potential actions taken by the political branches, the public, or some other source. Recognizing that even a single piece of legislation may contain a mix of threats, judges could, in response to this question, single out specific provisions or elements of threats that were more concerning to them. Overwhelmingly, judges reported that they believed there is a threat to judicial independence, a response consistent with our view that the judiciary is generally aware of its place in institutional context, its relationships with other political actors, and potential encroachments on its authority. Yet, the judges differed in their articulation of what actually constituted a threat. Several judges suggested that they are less likely to feel threatened by provisions that targeted judicial policies and more so by those aimed at different features of the judiciary itself. The majority of the participants contributed to a robust picture of the different observable threats they believed to require the most attention on the part of the judiciary. Almost every judge mentioned that chipping away at institutional authority by Congress posed the greatest harm to the judicial branch; a few judges also forwarded alternative perspectives on the source of threats. We explore the responses provided by participant judges on a thematic basis.

\section{Is There a Threat to Judicial Independence?}

Participant judges recognized (almost universally) that there are threats to judicial independence, with 25 of the 27 judges agreeing that a threat existed, as demonstrated in 
Table 2. Summary of Perceived Threats from the Legislature among Judges Interviewed (\%)

\begin{tabular}{lccccc}
\hline & $\begin{array}{c}\text { All } \\
\text { Judges }\end{array}$ & $\begin{array}{c}\text { District Court } \\
\text { Judges }\end{array}$ & $\begin{array}{c}\text { Appellate and } \\
\text { CIT Judges }\end{array}$ & $\begin{array}{c}\text { Democratic } \\
\text { Appointees }\end{array}$ & $\begin{array}{c}\text { Republican } \\
\text { Appointees }\end{array}$ \\
\hline $\begin{array}{l}\text { General complexion of the } \\
\text { threatening provision: }\end{array}$ & & & & & \\
Asymmetric/institution focused & 85 & 88 & 80 & 86 & 85 \\
Symmetric/policy heavy & 7 & 0 & 20 & 7 & 8 \\
$\quad$ None mentioned & 7 & 12 & 0 & 7 & 8 \\
Specific provision: & 15 & 18 & 10 & 21 & 8 \\
$\quad \begin{array}{l}\text { Retention/term limits } \\
\text { Salary/funding }\end{array}$ & 37 & 41 & 30 & 29 & 46 \\
$\quad \begin{array}{l}\text { Cameras in courtroom } \\
\text { Inspector general (focused on }\end{array}$ & 7 & 12 & 0 & 7 & 8 \\
$\quad$ loss of autonomy) & 30 & 24 & 40 & 29 & 31 \\
Sentencing Guidelines (focused & & & & & 23 \\
$\quad$ on loss of autonomy) & 19 & 24 & 10 & 14 & 23 \\
\hline
\end{tabular}

Note.-Percentages rounded; may not sum to $100 \%$. CIT $=$ Court of International Trade.

table $2 .{ }^{17}$ Explanations and additional information about the two judges who did not recognize a threat will be detailed later in the results section. Judges acknowledged the importance of judicial independence to the performance of the judiciary but noted that the barrage of threats to the institution by Congress in particular made it difficult to act as a coequal branch of the government. Further, judges posited that fostering judicial independence is a value that Congress shares with the judiciary, but only to the extent that the judiciary behaves in ways that Congress would support. Several judges elaborated on the nature of Congress's wavering support of an independent judiciary, suggesting, as one chief district judge remarked, that "judicial independence is absolutely critical and vital to the continued health of the country. If you go back and study American history closely, the other branches, particularly the legislature, have always been nipping at the heels of the judiciary. They [Congress] don't like the branch.”

Responses to this question directly addressed the tensions that tend to flare when the judiciary is perceived to do things that Congress would not support, with some respondents suggesting that judges would be better off if they modified their behavior to stave off threats. In the analysis of another district court judge, "I do think that there are constant threats to judicial independence. [Congress values it] in the abstract until they face rulings they disagree with, and then they want to rein in the judiciary. Judges need to be careful to not act in ways that invite these threats."

17. For the purposes of reliability, we recruited four additional raters and trained them to code the judges' responses. These raters agreed with $90 \%$ of our original coding decisions regarding judicial independence and the types of threats courts face. In the remaining cases where the raters split, we used a fifth coder to resolve the disagreement. 
But not all judges addressed this particular interbranch dynamic in this direct manner. If judges articulated that they believed there was a threat to the judiciary, we then asked what that threat looked like. This is a key facet of our inquiry. Since the above responses demonstrate that judges may have identified multiple threatening provisions (e.g., reactions by lawmakers to "rulings they disagree with" as well as proposals to impose, e.g., "term limits for judges") as valid responses to our initial question, we have reason to expect that the judges could articulate threats across the range of potential responses as particularly concerning during subsequent questioning. And indeed, in our follow-up query, judges provided a rich picture of the many observable varieties of threats they perceived as the most worrisome. However, the judges focused quite clearly on legislative provisions regarding the formal structure of the judiciary as most worthy of their attention. As one judge remarked, "I do think there are threats to judicial independence. The proposals range from amending the Constitution to eliminating lifetime tenure-that's [as] fundamental [a] threat as you can get." In the following section, we explore the different types of observable threats with a discussion of what judges consider to be a threat as compared to what they explicitly mentioned was not a threat.

\section{What Is Not a Threat to the Judiciary, and What Is a Threat?}

In response to our request to articulate an example of a threat to the judiciary, several judges compared and contrasted their relative lack of concern about policy-heavy threats to their heightened concern about institution-focused provisions. ${ }^{18}$ While the judges mentioned that blatant, policy-heavy attacks were something they were aware of, this type of threat only caused them concern when they were coupled with attempts to curb their institutional authority. One appellate judge detailed the nature of threats to the judiciary. In his response, he suggested that although overt, policy-heavy threats receive a lot of popular attention, the real threat to the judiciary is the deliberate chipping away at the institution by Congress: "I think that there are pressure points on the judiciary that didn't exist before, and I don't think they are going away any time soon. . . Some of [the threats are] fairly overt, and dramatic. [But] some of it is 'slow creep' - and the slow creep, I'm actually more concerned about this one. ... If you get nibbled to death incrementally, you wake up one day and you find yourself in the circumstance that your institution's independence has been eroded, and it becomes very difficult to push back."

Judges talked specifically about how they were not concerned about threats from Congress that were only based in policy. Judges mentioned that they viewed this type of threat as part and parcel of the separation-of-powers relationship and that such threats were not particularly worrisome. According to an appellate judge, "We've had some cases in [particular policy] areas, where we've had specific court rulings overturned by the legislative branch. I view that as a natural part of the separation of powers." Further, judges suggested

18. We use this terminology to indicate that judges tend to focus on certain aspects of legislation in their discussions, even though any one proposal may contain multiple "threatening" provisions. 
that they are aware of how their work in certain policy areas might have the tendency to contradict the will of the other branches but that they did not see this policy tension as something worth addressing by changing their behavior. Rather, they suggested that the political process provided a set of proper remedies. According to another judge, "There were plenty of calls to impeach Earl Warren because of immigration, prisoners' rights, etcetera." While this was unsettling, what occurred was more mundane. "You know, what happened was Nixon ran for president on the law and order ticket, promising to reverse the course of the Court. And he appointed justices and that is how he changed the Court. . . It is what the founders had in mind."

Instead of being concerned about changes to policy they have set, judges expressed heightened anxiety about institutional impingements. Speaking in the broadest terms, judges viewed any additional institutional control by Congress of the judiciary as troublesome. According to many of the judges, the concern over congressional infringement is always salient, as there "are encroachments. There is always a bill." For example, this judge continued, "there is a legislative idea to have an inspector general [and] there are also bills that say there must be cameras in the courtroom." Further, judges viewed any type of institution-focused provision as damaging to the judiciary's status as a coequal branch. One district court judge remarked that "any time you tell the judiciary, 'you have to do it this way' - that is when you lose the specter of independence.” This judge then provided a clear example of an institutional threat—budget slashing — stating, "They don't want to pay us." Another judge went on to say that the judiciary's "independence has been eroded because Congress imposes itself upon us" with its demand for cameras in the courtroom. "Congress," the judge noted, "seems hell-bent on this. ... The drama will be complicated and inflamed with a TV crew in your courtroom filming everything that happens." The same judge defined other impositions as attempts to amend the Constitution, impose term limits, and institute judicial elections, among other institutional threats. In other words, judges are acutely aware of the threats to their institution lodged by Congress. In fact, their awareness is so acute that it extends far beyond the range of their immediate experience. Several judges who mentioned a fear of judicial salary reductions or budgetary constraints recalled the case of United States $v$. Will (1980), which occurred before a majority of those surveyed were on the bench, including those who mentioned the case.

In total, 23 of the 25 judges who saw threats to judicial independence primarily characterized the most threatening provisions as institutional, whereas only two talked with concern about threats arising through other means. The two judges who did not articulate concerns about judicial independence were both district court judges and were fairly new to the courts. In the view of one of these two judges, who was in his first year on the bench at the time of the interview, "I wouldn't care if I did something that would be perceived as controversial. I guess my feeling is that judicial independence is probably pretty strong."

Other than these judges, it is worth noting that the vast majority were cognizant of policy-heavy threats, but they nonetheless tended to focus on institutional ones as particularly concerning. This is exemplified in the views of one district court judge concerned 
that "congressmen and senators are weighing in on 'how good' SC [Supreme Court] decisions are. Like, Senator [Ted] Cruz saying lifetime tenure should be taken away based on something [Chief Justice John] Roberts said. The more that people drag the judicial branch into the political battles, it is going to undermine the credibility of the judicial branch." In other words, this judge identified a policy basis for the legislature's disagreement but then honed in on what he perceived to be an improper institutional response on the part of Senator Cruz. Judges seldom spoke with greater concern about policy-heavy threats in our conversations. One appellate judge's perspective illustrated nicely the contrast between institutional threats and policy threats. The judge had a relatively benign view of the policy responses, acknowledging that judges "don't have free range to do whatever. . . . If I make a decision that [a member] doesn't agree with, [that member] could instead go up the stream and get the law changed." But the judge indicated that institutional threats were serious threats to independence. "The biggest threat to the judicial independence today," he said, "is an inspector general — who do they answer to and how is that done? Congress doesn't have one, and the thought of this is a threat to independence, but I'm not sure it is going to come to fruition. The mere discussion of it makes judges nervous."

\section{Observable Court-Curbing Threats Are a Significant Concern}

Almost every judge interviewed for this project mentioned at least one specific way that Congress limits the authority of the courts. Concerns over institutional authority ranged from threats to jurisdiction and decisional independence to those regarding judicial job security and control over the budget. Most importantly, no interviewee articulated a direct connection between her decisions (or the policy she has set) and Congress's—or the public's — disagreement with those decisions as worthy of her apprehension. To be clear, this does not forestall the possibility that such disagreement may prove to be a trigger for institutional threats, but rather it indicates that, absent an institutional threat, political or policy-based displeasure with the judiciary is not enough to significantly concern the judges we interviewed. ${ }^{19}$ We detail below several observable types of threats the judges explicitly mentioned in the interviews. As summarized in table 2, institutional provisions aimed at limiting judicial autonomy, instituting retention elections or term limits, slashing judicial budgets, and inducing other forms of oversight were each mentioned by multiple interviewees.

Many judges expressed concern about oversight provisions that would diminish their ability to make decisions without fear of retribution. Within this category of threats, approximately one-third of the judges specifically mentioned the threat of a bill recommending the establishment of an inspector general of the judiciary (eight judges). Inspector general proposals, which are forwarded frequently, would greatly increase the accountability

19. An interesting avenue for future research would be to explore the frequency and conditions under which political displeasure with the judiciary translates into institutional threats in Congress. 
of the judiciary through oversight of the activities of judicial and other institutional actors within the branch. Judges view the creation of an inspector general as an overreach of congressional power. As one judge remarked, "The potential legislation setting up an Inspector General ... presents serious separation of powers issues." By eliminating the future discretion that judges may exercise, this proposal clearly limits judicial independence. Although many judges are not convinced that such a measure would be enacted, the mere discussion of this accountability mechanism worries judges, particularly because judges have internal accountability mechanisms that they believe are intrusive and rigorous enough. According to one appellate judge, "I had to leave [a] board. . . . There was a little aspect to do with fundraising. An abundance of caution led to me to leave the [board]. Judges can't live lives like normal people, and this is a burden. The judiciary is scrupulous. The judiciary wants to avoid scandalous impropriety. [But] they don't get credit for that on Capitol Hill."

Judges who mentioned the threat of an inspector general also spoke about the nature of threats to the judiciary, suggesting that some threats are legitimate reactions to judicial decision making while others are not. This further highlights a tension between the dominant thread of scholarship on judicial independence, which sees policy-based responses as central, and the views of judges, who find policy-based responses as both expected and unproblematic congressional reactions. Judges think that there are certain actions Congress can take that are critical of the judiciary but within the legitimate realm of checks and balances, while other actions are damaging to the institution and are encroachments that extend past the legitimate scope of Congress's power.

Judges also perceived direct threats to their discretion as illegitimate encroachments by Congress. For example, five judges recollected their concerns over the creation of the Federal Sentencing Guidelines, a uniform spreadsheet of sentencing standards meant to assist federal judges in meting out punishments to those convicted of committing felonies and serious misdemeanors. These guidelines, in other words, limited judicial discretion quite sharply. One district court judge connected the debate about the Sentencing Guidelines to contemporary concerns about the balance of power between the institutions, suggesting that "things like mandatory minimums were illustrations of how Congress can invade the province of the judiciary and really corrupt the decision making process." Therefore, while the Sentencing Guidelines represent a complex mix of both institutional and policy-heavy threats to the courts, at least some judges perceive them as primarily a threat to their independent decision-making authority.

A final area of focus for the judges recalls work by Toma (1991). Judges viewed Congress's control of the judiciary's budget as damaging to the branch's status as a coequal branch. Almost $40 \%$ of the judges interviewed spoke directly to these concerns (10 judges). In response to the politicization of the budgeting process, a district court judge said that limiting the budget of the judiciary "threaten $[s]$ staffing and our ability to function ... in other words, in order to do the work that needs to be done. Cases have to be done more quickly than judges feel they are able to give their finest efforts towards. 
Just the size of the docket and the resources available threaten our independence." Another judge remarked that further structural constraints imposed by Congress "make it harder for [judges] to work." Judges have to work within the restrictions that are imposed upon their institution by Congress and recognize that those structural and budgetary limitations strain the capacity of the judiciary.

Additionally, judges suggested that they were worried about congressional attempts to change the nature of their positions. While several interviewees (15\%) expressed concern over threatened changes to judicial tenure, one district court judge provided an account that was particularly salient to our inquiry: "When the courts take actions that cancel out the political process ... there are temptations amongst some in the political branches to do something about those courts that are out of control. There are discussions of term limits for judges, no more life tenure, [to] amend the constitution [so that] judges at the federal level need to be elected. ... These are proposals that begin to erode independence. [Congress is] perfectly happy for us to be independent when we agree [with them] — but when we don't, they look for ways to rein us in." This comment is further demonstration of how judges articulate the nature of the relationship between the courts and Congress. When judges perceive that Congress is not pleased with their actions, the threats judges are most likely to communicate are to the institutional design features of the judiciary itself, as opposed to changes to the policy set by the judiciary. In the words of another district court judge, "We have a senator calling for the end of lifetime appointments. If people campaign to get rid of bedrock principles in the Constitution ... it isn't good for the overall system to suggest changing the judicial system itself."

\section{Alternative Perspectives}

Although most interviewees agreed that judicial independence is threatened and that those threats come in a specific institutional form from Congress, a few judges had different ideas about the nature of threats - and two did not think that a threat exists at all. One judge suggested that judicial independence was most threatened by the media and its politicization of decisions made by the courts. This appellate judge expressed concern about the role of the media in delegitimizing the actions of courts by "[ giving] an impression that everything [that happens in the judiciary] is political." Another judge took this logic a step further, suggesting that members of Congress have the opportunity to shape the public's view of the courts, which in turn could have negative effects for the judiciary in an institutional sense:

What we should really worry about is the public understanding our role, respecting us, individually and in our role- because then ... politicians will stay fairly close to [that level of respect] and we'll do okay. But, the representatives and senators get to affect how the public views us. If there is a flood of [criticism by members of Congress], that is a signal [of a threat]. If they can do that and get elected and push those themes ... heaven forbid that would spark a constitutional amendment. That would really do away with judicial independence. 
In this judge's account, threats to public legitimacy may lead to institutional threats about which the judiciary is concerned. This view, while not articulated by any other judge, recalls Clark's $(2009,2011)$ perspective on the mechanisms that underlie court-curbing behavior by members of Congress.

\section{Investigating Consequences for Judicial Behavior}

A number of judges indicated that institution-focused threats caused them to adjust their behavior so as to forestall the most disquieting congressional attacks. Indeed, even though proposals that threaten the courts do not frequently become law, leading some to question their impact (Ross 2002), judges indicate that they remain vigilant. Past instances in which the courts were successfully constrained by Congress (e.g., via the enactment of the Sentencing Guidelines) are still on the minds of many judges (see table 2). Judges may also view institution-focused provisions, regardless of their passage (e.g., the forwarding of inspector general proposals), as signals about other impending dangers that lie ahead, such as declining popular support for the judiciary (Clark 2009).

One district court judge indicated the need for the judiciary to emphasize in its opinions the legitimacy of its actions to contend with these threats, stating, "We only have- to uphold our legitimacy - the power of our reasoning and what we say." Not only does this view echo other research (e.g., Black et al. 2016) in its suggestion that judges aim to buttress the legitimacy of their opinions by adjusting the rhetoric they employ, but it also adds to this literature by identifying an additional impetus for this behavior: observable institutional threats from Congress. This same judge goes on to identify two additional steps that judges take in response to institutional threats by noting the need to demonstrate compliance with superior court instructions and obfuscate one's own political views. One implication is that, to the extent judges are increasingly concerned about institutionfocused threats, we may observe more opinions written in a way that highlights their legitimacy yet obscures their policy impact. A second judge also represented this view and suggested that if a judge were perceived as "overreaching" his authority, Congress could react negatively and impose institutional curtailments, like an inspector general. He advocated for judges to have awareness of their behavior (in and outside of the courtroom) in order to avoid congressional threats: "Judicial overreaching can endanger [the] judiciary. .. . Judges have to approach their work with humility, know the core of judicial independence, and act in a way that fosters legitimacy. . . . If judges act ethically, avoid public commenting, avoid conflicts of interest-those are things judges need to do. We have to be mindful of proposals [for] inspector generals. If they were to gain traction, they need to be enacted without institutional encroachment."

Other judge interviews also indicated how concerns over institution-focused threats affect the behavior of courts. Institutional threats may be particularly disconcerting to judges relative to policy-based responses, given their views about how the political system should operate. In other words, the separation-of-powers system in the United States serves as a blueprint for actors within federal institutions, detailing the scope of their in- 
stitution's internal powers, as well as their range of checks on the power of the other branches. Additionally, this system, along with the past behaviors and normative expectations of the actors within it, provides judges with an understanding of what kinds of activities are considered to be proper or not. ${ }^{20}$ Most dramatically, one judge suggested that, under threat, courts might be forced to abandon their traditional function of safeguarding minority rights out of fear for legislative reprisal:

Legislators expect us to provide meaning that they were unable to provide because of their political requirements of compromise. That's not undue judicial activism. That is a kind of a dance that the two branches do. We are just doing what we are expected to do.... Given the kind of decisions federal judges have to make, our responsibility to enforce minority rights, to make decisions counter to majority views - you could not have a system that allows a judiciary to do that job in the way it should if you do not have judicial independence. . . It is frustrating when these institutional [infringements] result from the job the legislature expects us to do.

Similarly, another judge suggested that (although it may happen infrequently) judges consider altering their behavior in order to reach decisions that are "correct" in the eyes of legislators, saying, "[ Whereas legislators] seek the right political answer . . the courts cannot achieve that if they are doing their job correctly... . There is a temptation by many judges to reach correct political decisions, but it doesn't happen as often as we think" (emphasis added).

In short, a number of judges indicated that institutional threats compelled them to adjust their behavior in a variety of ways. Because many judges evinced concern with what they perceive as an increase in congressional threats, our findings imply that judges may make greater use of strategies to buttress the bench's legitimacy going forward. To take one prominent example from our interviews, it is possible that judges may increasingly use language that makes it less clear whether their actions run afoul of Congress, a behavior that has potential consequences for the judiciary's ability to induce compliance (Stanton and Vanberg 2008). As such, our inquiry indicates that institutional threats do not need to pass into law to influence judicial behavior, given the high level of concern that federal judges evince over them.

20. Of course, the separation-of-powers framework does, in fact, build in the ability for the branches to check the formal authority of one another. However, a powerful norm has developed over the course of American political history that politicized inference with the courts is improper. So, e.g., while politically motivated impeachment threats represented a serious danger to the institution during Reconstruction (Epstein and Walker 1995), similar threats have almost never been actualized in the modern era, although their proposal is fairly commonplace (Geyh 2006; Farganis 2009). It is therefore our point that current judges may perceive certain attacks on the judiciary as improper. 


\section{Results in Summary}

Overall, an overwhelming majority of federal judges we interviewed recognized threats to judicial independence. While many were cognizant of the mix of threats they face, most of these judges drew a distinction between policy-heavy responses, such as congressional attempts to reverse unwanted decisions, and institution-focused threats. The judges generally viewed policy-heavy responses as proper and remained unalarmed by them. On the other hand, they expressed consistent worry about proposals to court curb, by introducing oversight of the judiciary, limiting budgets, and setting term limits, among other proposals. Judges are concerned that these threats are becoming more prominent. As a consequence, several judges suggested that they felt compelled to react to the threats about which they were most concerned by altering their behavior in public and the courtroom as well as their opinions in critical cases.

\section{DISCUSSION}

The purpose of this project was to bring attention to developments in the study of the relationship between Congress and the judiciary and, more importantly, to identify and explore opportunities for the growth of additional scholarship in this area. Most importantly, we found that judges were highly unlikely to articulate a legislative change to the policy they set as a provision that concerned them. They instead provided many examples of how institution-focused provisions give them pause.

As such, the contributions of this article are threefold. First, we shift the traditional approach in the separation-of-powers literature. While existing work focuses primarily on observable indicators of judicial behavior associated with decision making, we enrich our understanding of the factors that motivate judges by exploring the microlevel mechanisms they claim govern their behavior. By going directly to judges to interrogate questions about judicial independence, we hope to show an important distinction in terms of how judges interpret the variant threats to their authority. Second, in speaking with judges, we are able to detect a tension between the threats to judicial authority that they view as most disconcerting and those on which existing scholarship pools. One implication is that existing work has not adequately emphasized some of the adjustments that judges indicate they make when concerned about institutional threats. Rather than alter policy decisions, judges suggested to us that they are increasingly emphasizing the legitimacy of their opinions and institutions whenever possible. This is the case even if there is only a slight possibility that Congress will be able to pass court-curbing legislation.

Third, we extend current analyses to those levels of the judicial hierarchy that are traditionally overlooked in explanations of this institutional interplay. This broadened focus makes even more plain the degree to which institution-focused provisions are disconcerting, for a pair of reasons. One, lower court judges have less reason to be concerned about policy reversals from Congress because they must first worry, from a policy-based perspective, about being reversed by an appellate court (Klein and Hume 2003). This reversal may be much more costly to a lower court judge than any legislative sanction. Another reason 
that lower court judges may weigh institutional threats heavily is that they are potentially more vulnerable to the gradual legislative erosion of institutional authority than their counterparts on a more visible superior court. Indeed, some lower court judges expressed this very view to us during our interviews. We also wish to reinforce that we do not doubt that policy-heavy threats are important or that they may shape judicial behavior, but important forms of institutional threat have been woefully neglected.

Why should scholars care about this misplaced emphasis? In any given context, it is likely the case that multiple threats to the judiciary may be present. The vast majority of existing work considers these threats in isolation, attributing strategic behavior to a concern about either policy reversal (e.g., Harvey and Friedman 2006) or institutional sanction (e.g., Clark 2009). Yet, judges themselves articulate the tangle of policy-based threats and institutional curtailments: "In the current political climate, there are a lot of things that are being said that are very unhelpful—destructive to the system. Recent decisions by the [Supreme] Court that have caused members of Congress to start to propose major changes in the way judges are selected or retained. That is not new, these things have been proposed before. But, the tone we have now is different, and also not helpful." As a consequence, scholars have neither a systematic sense of which threats judges themselves may give more weight nor a complete picture of the interbranch dynamics judges encounter. Observations like these motivate further study of the "complete" range of congressional threats the judiciary confronts, as these assessments may lead to different forms of behavior across a variety of scenarios.

Additional scholarship, which focuses on the nature of court-curbing behavior by Congress and the likelihood of a court's responsiveness to those threats, is reinforced by the findings of this analysis. The results of this project suggest that scholars interested in interbranch dynamics would do well to reconsider how to identify the institutional underpinnings of policy-based threats and to give more attention to the threats that members of the judiciary tend to cite as the most concerning. This observation fits squarely within a long tradition of scholarship that sees judges as sophisticated, strategic actors, in spite of the fact that much of the work in this area imposes assumptions about what judges may care about that do not square with what they themselves tell us. However, we also find that judges appear increasingly concerned about threats, a fact not detected by the literature.

Further, this project stands to motivate additional scholarship on observable, strategic responses across the judicial hierarchy to congressional threats. Our research demonstrated that it is not only Supreme Court justices who are paying attention to these interbranch dynamics, but indeed judges in the lower federal courts also conceive of threats and consider how to moderate their behavior to stave off attacks. In fact, one lower court judge spoke about how he strategically crafts decisions to hew closely to appellate court rulings in order to avoid scrutiny: "It is so important in my view to do everything I possibly can to show that any decision I release or rule on as strictly following what the superior courts tell me to do. I do not want stray writing to tip off what my political views might be on a particular issue." In his view, drifting from this methodical approach may harm Congress's 
view of the judiciary “as some benign agency, [like NASA]," and threaten Congress's funding and support of the courts.

Although we recognize that the elite interview approach has its limitations, it offers significant comparative value since so little of the contemporary literature seeks a fuller understanding of judicial motivations directly from the source. Future research could consider how to develop a sampling strategy that would result in a more balanced sample of the judiciary. We are careful in making claims about generalizability to the judiciary as a whole but contend that this project is a valuable starting point for understanding interbranch relationships more broadly defined.

Our interview data also allowed us to gain insights about the specific types of threats judges found most worrisome. Scholars may be able to use these categories to investigate how certain types of threats are forwarded and whether they lead to a response by the judiciary. Further, we found that only district judges (but only two of them) said that they did not feel as though judicial institutions were threatened. We think another interesting area of inquiry would be to explore how trial judges differ from appellate court judges in their perception of threats from Congress — or other sources — given their distance from the most politicized or salient court of their branch, the Supreme Court. We anticipate that a more nuanced understanding of these conditional factors will only further contribute to our knowledge about judicial behavior in a separation-of-powers context.

\section{REFERENCES}

Black, Ryan C., Ryan J. Owens, Justin Wedeking, and Patrick C. Wohlfarth. 2016. U.S. Supreme Court Opinions and Their Audiences. Cambridge: Cambridge University Press.

Bowie, Jennifer Barnes, and Donald R. Songer. 2009. "Assessing the Applicability of Strategic Theory to Explain Decision Making on the Courts of Appeals." Political Research Quarterly 62:393407.

Bowie, Jennifer Barnes, Donald R. Songer, and John Szmer. 2014. The View from the Bench and Chambers: Examining Judicial Process and Decision Making on the US Courts of Appeals. Charlottesville: University of Virginia Press.

Clark, John A., and Kevin T. McGuire. 1996. "Congress, the Supreme Court, and the Flag." Political Research Quarterly 49 (4): 771-81.

Clark, Tom S. 2009. "The Separation of Powers, Court Curbing, and Judicial Legitimacy." American Journal of Political Science 53 (4): 971-89.

. 2011. The Limits of Judicial Independence. Cambridge: Cambridge University Press.

Epstein, Lee, and Jack Knight. 2013. "Reconsidering Judicial Preferences." Annual Review of Political Science 16:11-31.

Epstein, Lee, and Thomas G. Walker. 1995. "The Role of the Court in American Society: Playing the Reconstruction Game.” In Contemplating Courts, ed. Lee Epstein. Washington, DC: CQ.

Farganis, Dion. 2009. "Court Curbing in the Modern Era: Should Supreme Court Justices Really Worry about Attacks from Congress?” https://papers.ssrn.com/sol3/papers.cfm?abstract $\_$id $=1430723$.

Ferejohn, John A., and Barry R. Weingast. 1992. "A Positive Theory of Statutory Interpretation." International Review of Law and Economics 12 (2): 263-79. 
Geyh, Charles G. 2006. When Courts and Congress Collide: The Struggle for Control of America's Judicial System. Ann Arbor: University of Michigan Press.

Graber, Mark A. 1993. "The Nonmajoritarian Difficulty: Legislative Deference to the Judiciary." Studies in American Political Development 7 (1): 35-73.

Harvey, Anna, and Barry Friedman. 2006. "Pulling Punches: Congressional Constraints on the Supreme Court's Constitutional Rulings, 1987-2000." Legislative Studies Quarterly 31 (4): 53362.

Klein, David E., and Robert J. Hume. 2003. "Fear of Reversals as an Explanation of Lower Court Compliance." Law and Societv Review 37 (3): 579-81.

Kvale, Steinar, and Svend Brinkmann. 2009. InterViews: Learning the Craft of Qualitative Research Interviewing. New York: SAGE.

Landes, William M., and Richard A. Posner. 1975. "The Independent Judiciary in an Interest Group Perspective." Lournal of Law and Economics 8 (3): 875-901.

McMillion, Barry J. 2014. "U.S. Circuit and District Court Judges: Profile of Select Characteristics." Congressional Research Service R43426. https://fas.org/sgp/crs/misc/R43426.pdf.

Moyer, Laura, and Ellen M. Key. 2016. “'Why’s Everybody Always Picking on Me?' Court Curbing Legislation and the Ninth Circuit." Paper presented at the Midwest Political Science Association Annual Conference, Chicago.

Nagel, Ilene H., and Winthrop M. Swenson. 1993. "The Federal Sentencing Guidelines for Corporations: Their Development, Theoretical Underpinnings, and Some Thoughts about Their Future." Washington University Law Quarterly 71:205-59.

Nagel, Stuart S. 1964. "Court-Curbing Periods in American History." Vanderbilt Law Review 18 (June): 925-44.

Patton, Michael Q. 1990. Qualitative Evaluation and Research Methods. New York: SAGE.

Posner, Richard A. 2010. How Judges Think. Cambridge, MA: Harvard University Press.

Rogers, James R. 2001. "Information and Judicial Review: A Signaling Game of Legislative-Judicial Interaction." American Journal of Political Science 45 (1): 84-99.

Rosenberg, Gerald N. 1992. "Judicial Independence and the Reality of Political Power." Review of Politics 54 (3): 369-98.

Ross, William G. 1994. A Muted Fury: Populists, Progressives, and Labor Unions Confront the Courts, 1890-1937. Princeton, NJ: Princeton University Press.

— 2002. "Attacks on the Warren Court by State Officials: A Case Study of Why CourtCurbing Movements Fail.” Buffalo Law Review 50:483-612.

Sala, Brian R., and James F. Spriggs. 2004. "Designing Tests of the Supreme Court and the Separation of Powers." Political Research Quarterly 57 (2): 197-208.

Segal, Jeffrey A. 1997. "Separation-of-Powers Games in the Positive Theory of Congress and Courts." American Political Science Review 91 (1): 28-44.

Segal, Jeffrey A., Chad Westerland, and Stefanie A. Lindquist. 2011. "Congress, the Supreme Court, and Judicial Review: Testing a Constitutional Separation of Powers Model." American Journal of Political Science 55 (1): 89-104.

Songer, Donald R., Reginald S. Sheehan, and Susan B. Haire. 2000. Continuity and Change on the United States Courts of Appeals. Ann Arbor: University of Michigan Press.

Stanton, Jeffrey K., and Georg Vanberg. 2008. "The Value of Vagueness: Delegation, Defiance, and Judicial Opinions." American Journal of Political Science 52 (3): 504-19.

Tansey, Oisín. 2007. "Process Tracing and Elite Interviewing: A Case for Non-probability Sampling." PS: Political Science and Politics 40 (4): 765-72.

Toma, Eugenia Froedge. 1991. "Congressional Influence and the Supreme Court: The Budget as a Signaling Device.” Lournal of Leoal Studies 20 (1): 131-46. 
Ura, Joseph Daniel, and Patrick C. Wohlfarth. 2010. “'An Appeal to the People’: Public Opinion and Congressional Support for the Supreme Court." Lournal of Politics 72 (4): 939-56.

Vanberg, Georg. 2001. "Legislative-Judicial Relations: A Game Theoretic Approach to Constitutional Review." American Iournal of Political Science 45 (2): 346-61.

Whittington, Keith E. 2003. "Legislative Sanctions and the Strategic Environment of Judicial Review." International Journal of Constitutional Law 1 (3): 446-74.

. 2005. "'Interpose Your Friendly Hand': Political Supports for the Exercise of Judicial Review by the United States Supreme Court.” American Political Science Review 99 (4): 583-96. 